\title{
Modelling the Early Weichselian Eurasian Ice Sheets: role of ice shelves and influence of ice-dammed lakes
}

\author{
V. Peyaud, C. Ritz, and G. Krinner \\ Laboratoire de Glaciologie et de Géophysique de l'Environnement, Université Joseph Fourier 54, rue Molière, Domaine \\ Universitaire, BP 96, 38402 Saint Martin d'Hères Cedex, France
}

Received: 9 November 2006 - Published in Clim. Past Discuss.: 26 January 2007

Revised: 14 May 2007 - Accepted: 20 June 2007 - Published: 2 July 2007

\begin{abstract}
During the last glaciation, a marine ice sheet repeatedly appeared in Eurasia. The floating part of this ice sheet was essential to its rapid extension over the seas. During the earliest stage ( $90 \mathrm{kyr} \mathrm{BP})$, large ice-dammed lakes formed south of the ice sheet. These lakes are believed to have cooled the climate at the margin of the ice. Using an ice sheet model, we investigated the role of ice shelves during the inception and the influence of ice-dammed lakes on the ice sheet evolution. Inception in Barents sea seems due to thickening of a large ice shelf. We observe a substantial impact of the lakes on the evolution of the ice sheets. Reduced summer ablation enhances ice extent and thickness, and the deglaciation is delayed by 2000 years.
\end{abstract}

\section{Introduction}

The last glacial period witnessed the growth and decay of a large ice complex over the North Eurasia. Geological evidences suggest that the first glacial event occurred around $90 \mathrm{kyr}$ BP. This glaciation was probably due to a low insolation during summer and an increase in snowfall (Ruddiman and McIntyre, 1981; Jackson and Broccoli, 2003). In this paper we focus on the Early Weichselian in Eurasia (MIS5b $\sim 90 \mathrm{kyr}$ BP), as this short event started and finished with almost ice free conditions and can be treated independently of the rest of the glaciation.

At that time, a large ice sheet covered the Barents and Kara seas. It extended all over the continental shelf. In the North it leaned against the Arctic archipelago (Svalbard, Franz Joseph Land and Severnaya Zemblya), southward, it spread over Siberia, beyond the present coastline. This ice sheet was mostly marine, that is, its base was below sea-level. Therefore, the Barents-Kara ice sheet was most probably un-

Correspondence to: V. Peyaud

(peyaud@lgge.obs.ujf-grenoble.fr) stable and very sensitive to oceanic influence, similar to the West Antarctic ice sheet today (Oppenheimer, 1998). Thus, the role of the floating part (ice shelf) might have been essential during its inception and disintegration.

According to the conclusion of the QUEEN project (Svendsen et al., 2004), the Barents-Kara ice sheet was coalescent with an ice dome located over Scandinavia on the West, and with the Putorana ice cap on the East (see Fig. 1). This ice complex put up a dam that stopped the northward drainage of Siberian rivers. The large ice-dammed lakes created south of the ice were shown to have cooled regional summer climate (because of their large heat capacity) and modified precipitation (through mesoscale atmospheric feedbacks) (Krinner et al., 2004). These effects reduced the ablation and thus were inferred to enhance ice sheet growth. To complement the study by Krinner et al. (2004), which discussed the impact of ice-dammed lakes on climate, we want to investigate in more detail the lakes influence on the ice sheets.

To this end, we use a numerical ice sheet model to reconstruct the geometric evolution of the ice sheet. This model features ice shelves as well as grounded ice and allows us to test different assumptions for the glaciation of this area. In contrast to previous studies using a calving parameter to determine the limit of grounded ice (Zweck and Huybrechts, 2005; Siegert et al., 2001), we applied for the first time a model of grounded and floating ice to a whole northern ice sheet.

We describe briefly the ice sheet model and the climate forcing, adapted from Krinner et al. (2004), in the Sect. 2. Then we discuss the mechanism of the marine ice sheet inception and waxing. To do this, we present in the 3rd section, the different reconstructions taking (or not) into account the impact of the ice-dammed lakes and discuss their plausibility in the Sect. 4.

Published by Copernicus Publications on behalf of the European Geosciences Union. 


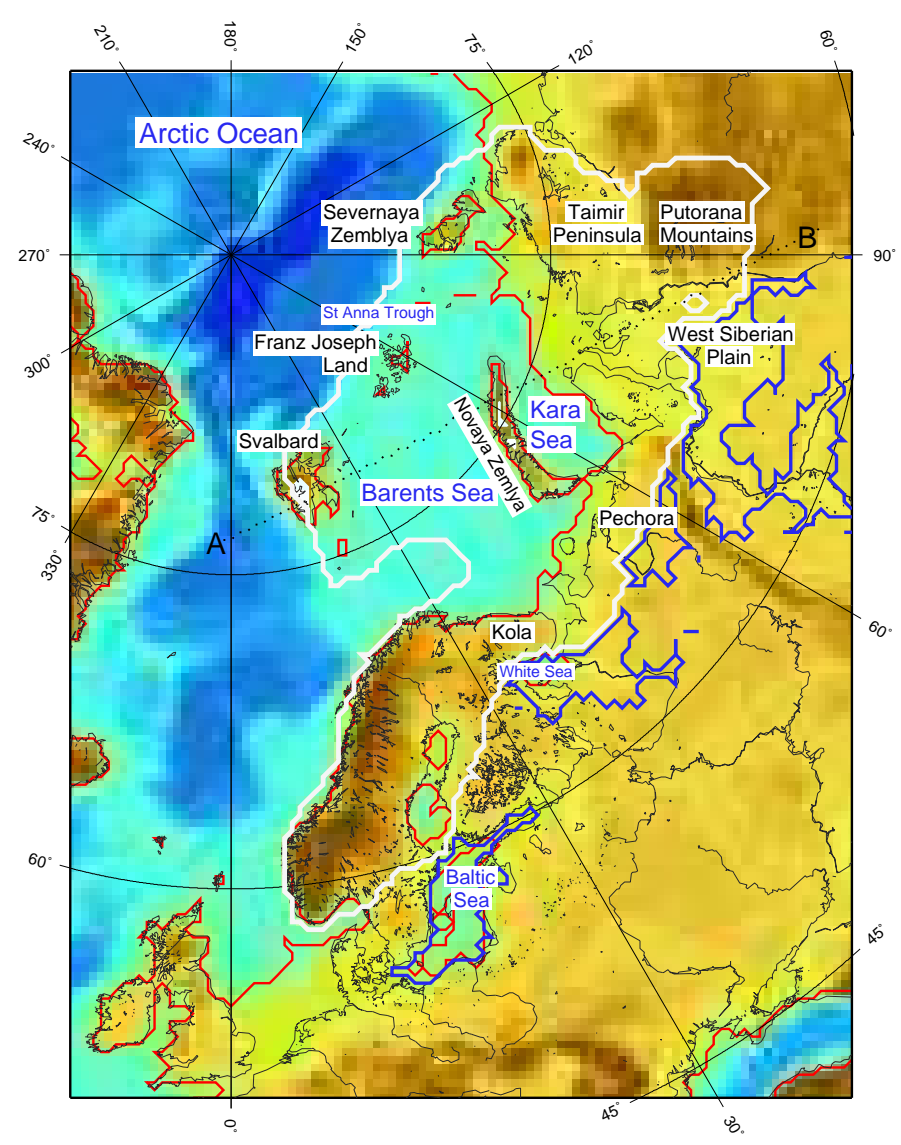

Fig. 1. Site map with names used in the text. The limit of the QUEEN ice sheet reconstruction is pictured in white, The extent of ice dammed lakes with a thick blue line. Present day coast and rivers are pictured with a blue thin line. The coast line, with a sea level drop of $-50 \mathrm{~m}$, is depicted in red.

\section{Experiments}

\subsection{Ice sheet model description}

We use the GRISLI ice sheet model (ISM) to reconstruct the ice sheet topography during the $90 \mathrm{kyr}$ BP glacial event. GRISLI simulates the dynamics of grounded ice as well as ice shelves and ice stream regions. Inland ice deforms according to the stress balance using the shallow ice approximation (Morland, 1984; Hutter, 1983). Ice shelves and dragging ice shelves (ice streams) are described following MacAyeal (1989). This 3-D model has been developed and validated over Antarctica by Ritz et al. (2001). A comprehensive description of the model is given by these authors. We therefore simply present recent improvements:

1. Thermomechanical coupling is extended to the ice shelves and ice streams. Ice viscosity - depending on the temperature field - is integrated over the thickness.
2. Basal drag under ice streams is related to ice velocity ( $\tau_{b}=\beta U$, where $U$ is the horizontal velocity). The factor $\beta$ depends on the effective pressure $N: \beta=-c f \times N$, where $c f$ is constant.

3. We compute basal water drainage with a Darcian flow into a sediment layer. The thickness of the sediment layer is set to the ad-hoc value of $50 \mathrm{~m}$. This description is too simplistic to account for the real basal processes. Nevertheless Darcian flow allows us to catch the drainage patterns.

4. Location of the ice streams is determined by the basal water head. Ice stream regions correspond to areas were the sediment layer is saturated.

5. Ice shelf front positions are determined with a scheme where two criteria must be fulfilled. To calv the ice on the front grid point, first, the ice thickness must decrease below $150 \mathrm{~m}$. This corresponds to the thickness of most observed ice shelf fronts. Secondly for each grid point at the front, the ice coming from the upstream points must fail to maintain a thickness above the threshold. This ability to maintain a sufficient thickness is estimated on the basis of a semi-Lagrangian scheme. Ice shelf front position changes at each time step, and appropriate boundary conditions, adapted from Rommelaere and Ritz (1996) and Ritz et al. (2001), are applied for the different front configurations. Atmospheric conditions have an implicit control on ice shelves. Indeed the surface mass balance prevents the ice sheves to form in warm regions (Mercer, 1978). Simulations of West Antarctica Ice shelves give front positions similar to observations. This method will be presented in a future publication.

\subsection{Input maps}

In this work, we use an horizontal resolution of $40 \mathrm{~km}$. We assume that the initial bedrock was similar to present. Since no large glaciation is known in this area between the Saalian (140 000 years ago) and $90 \mathrm{kyr}$ BP (Svendsen et al., 2004), no isostatic effects should deform the bedrock. Bedrock elevation and bathymetry is given by the ETOPO2 dataset. Isostatic response is described by the ELRA (for elastic lithosphere-relaxed asthenosphere) method (Le Meur and Huybrechts, 1996). This deflection is partly responsible for the formation of ice-dammed lakes and is discussed in the discussion (Sect. 4.3). We apply a heterogeneous geothermal heat flux from Shapiro and Ritzwoller (2004).

\subsection{Climate forcing}

\subsubsection{AGCM climatic fields}

In order to reconstruct the Eurasian Ice Sheet during the $90 \mathrm{kyr}$ event, we make use of climate simulations 
performed by Krinner et al. (2004). These authors used the LMDZ3.3 (Laboratoire de Météorologie Dynamique, CNRS Paris) stretched-grid atmospheric general circulation model (AGCM) to investigate the Eurasian climate around $90 \mathrm{kyr}$ before present (BP). They carried out three simulations, a present-day reference (henceforth GCM-P) and two simulations for $90 \mathrm{kyr}$ before present (BP). One included icedammed lakes (GCM-LA), the other did not (no lakes, or GCM-NL). Eurasian precipitations and summer (JJA) air temperatures at two meters above the surface are shown in Fig. 2. Compared to the present day climatology, the simulated climate for the present (GCM-P) gives appropriate temperatures, but precipitation is overestimated by more than $60 \%$ over the Eurasian continent, as stated by Krinner et al. (2004).

The simulated surface air temperature anomaly at $90 \mathrm{ky}$ BP (difference to the present-day climate) is strongly negative over the ice sheets and the oceans. This is caused by the prescribed SSTs, ice sheet extent (albedo and topography), and lower greenhouse gas (GHG) concentrations. However ice-free continents are warmer at $90 \mathrm{kyr}$ during summer (JJA). The $90 \mathrm{kyr}$ simulation are performed with a summer (JJA) insolation ( $496 \mathrm{~W} \mathrm{~m}^{-2}$ at solstice) higher than at $0 \mathrm{kyr}$; this overcompensates for the cooling induced by lower GHG concentrations, sea surface temperatures and adjacent ice sheets. This warming is confined south of the ice sheet. On the ice sheets, the cooling effects of high snow albedo and surface elevation are preponderant. Precipitation is higher than at present in the $90 \mathrm{kyr}$ simulations, especially over the Scandinavian mountains, the Barents Sea and around the Siberian coast (see Fig. 2).

\subsubsection{Surface mass balance of the ISM}

We use the AGCM air temperature and precipitation to reconstruct the climate at the surface of the ice sheet model following Charbit et al. (2002) who adapted AGCM outputs to the ISM surface. The significant difference with respect to that work is that we apply AGCM climate directly to the ISM surface instead of the relative differences between $90 \mathrm{kyr}$ and control (P) climate.

Temperatures at the ice sheet surface are given by the AGCM air temperature at $2 \mathrm{~m}$ above the surface. We used the mean annual temperature and the averaged summer (JJA) temperature. Temperature is corrected for altitude changes calculated by the ISM. Vertical temperature gradient is set to $-5^{\circ} \mathrm{C} \mathrm{km}^{-1}$ during summer and to $-6^{\circ} \mathrm{C} \mathrm{km}^{-1}$ for averaged annual temperature. These gradients are weaker than in Charbit et al. (2002) and motivated by results from observations (Fortuin and Oerlemans, 1990; Marshall et al., 2007) and AGCM simulations (Krinner and Genthon, 1999).

We assume that precipitation depends on annual temperature with an exponential law reflecting the saturation water pressure (Charbit et al., 2002). Accumulation is the solid fraction of the total precipitation. Ablation is calculated ac-
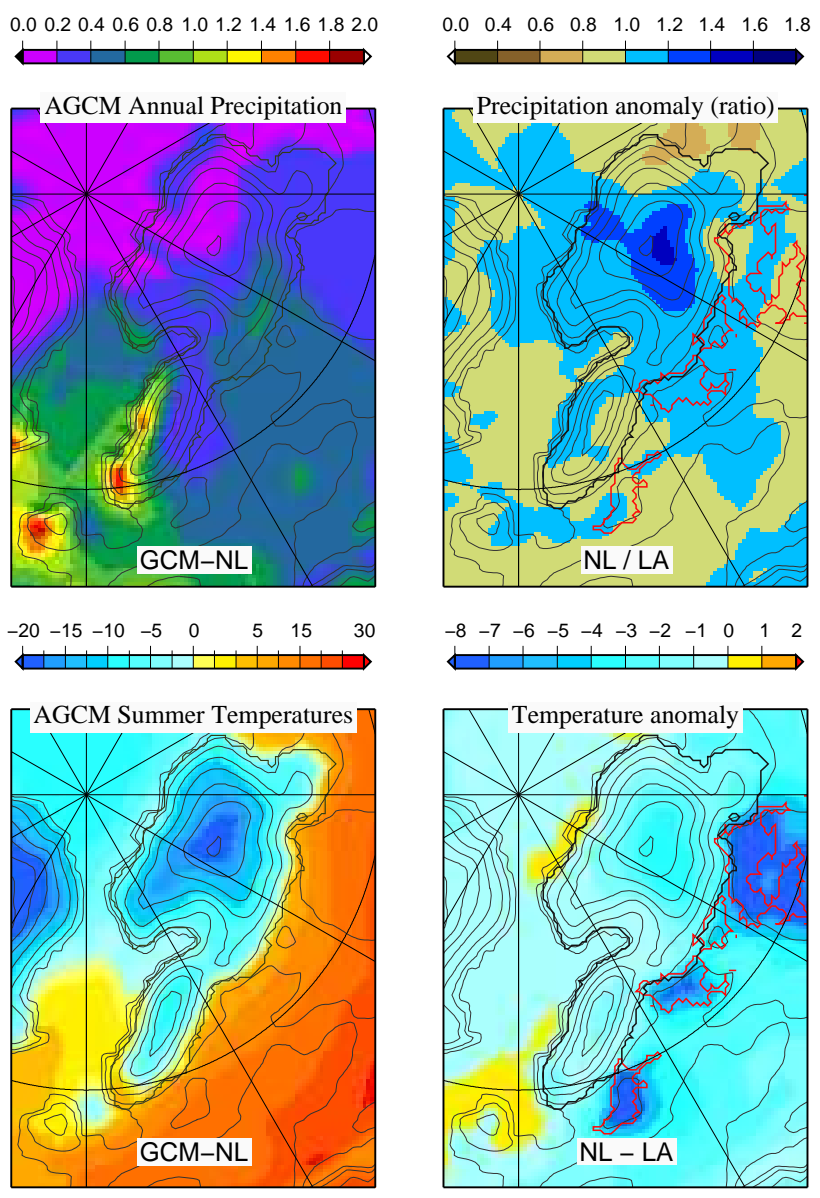

Fig. 2. AGCM climat at $90 \mathrm{kyr}$ without lakes (GCM-NL) On the left: on top: precipitation $\left(\mathrm{m} \mathrm{a}^{-1}\right)$ and summer temperature in ${ }^{\circ} \mathrm{C}$ (average from June July and August,) on bottom. On the right: anomaly between climate for (GCM-NL) and (GCM-LA) reflecting the influence of the lake: ratio of precipitation and temperature differences. The QUEEN ice sheet and lake extent are depicted with a black and red line.

cording to a positive degree day method (Reeh, 1991). The melting coefficients have been chosen in order to fit with AGCM ablation at $90 \mathrm{kyr}$. They are equal to $C_{\text {snow }}=8 \mathrm{~mm}$ ${ }^{\circ} \mathrm{C}^{-1} \mathrm{~d}^{-1}$ for snow, and $C_{\text {ice }}=17 \mathrm{~mm}^{\circ} \mathrm{C}^{-1} \mathrm{~d}^{-1}$ for ice. The discrepancies between our coefficients and those given by Reeh (3 times lower) are due to our calculation of PDD assuming a sinusoidal variation of temperature through the year - that probably underestimates extreme temperatures. A fraction of the melting is likely to refreeze. As in the AGCM (Krinner et al., 2006) this fraction increases as the amount of melting compared to snow fall decreases.

\subsubsection{Forcing method}

The forcing method is presented in the Fig. 3. In order to make a dynamical experiment through the glacial event, we 


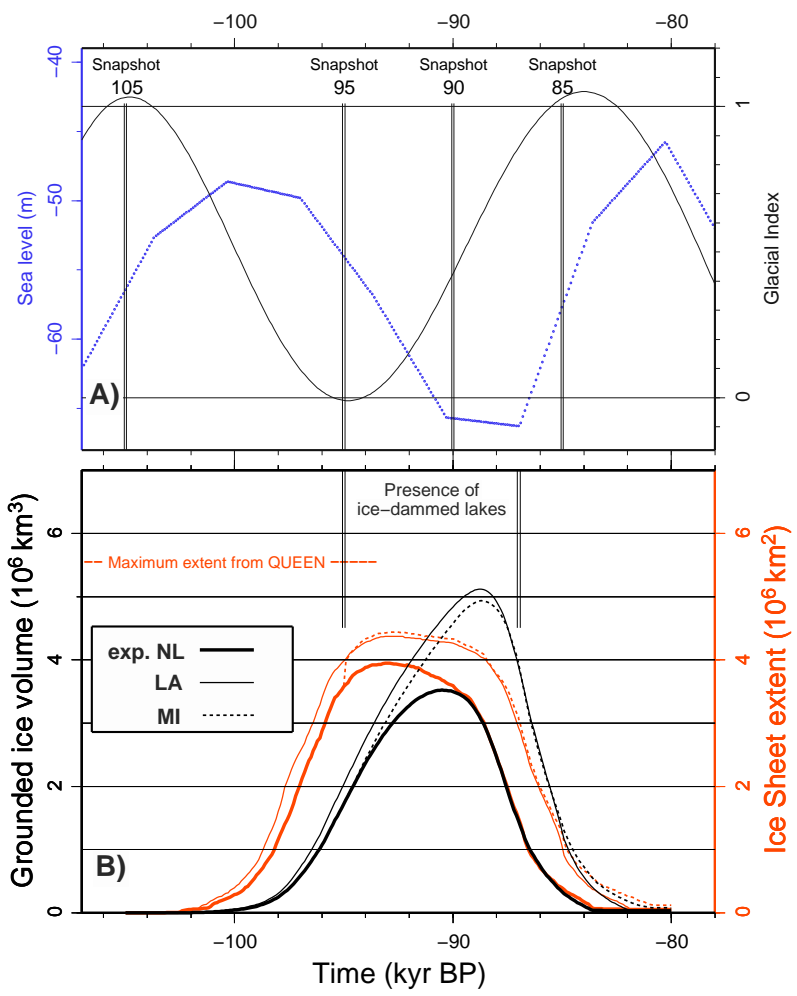

Fig. 3. Forcing method: 4 climatic anomaly snapshots adapted from the AGCM are applied at 105, 95, 90 and $85 \mathrm{ky}$ BP. The climatic anomaly applied at the ISM surface evolves between the snapshots according to a glacial index (summer insolation at $65^{\circ} \mathrm{N}$ ). Climate is colder when glacial index is 0 . Sealevel variation are plotted with a blue dotted line (Shackleton et al., 1990). (b) Variation with time of ice sheet volume (black lines) and extent (orange lines) for the 3 experiments.

assume that the imposed surface climate is driven by summer insolation. We use 4 climate snapshots at 105, 95, 90 and $85 \mathrm{kyr}$ ago derived from the AGCM simulations. The temperatures and precipitations at any time between these dates is obtained by an interpolation between two snapshots (for instance at $87.5 \mathrm{kyr}$ we used the 90 and $85 \mathrm{kyr}$ snapshots) that vary in time with the $65^{\circ} \mathrm{N}$ solstice summer insolation (Paillard et al., 1996), as presented below.

The $90 \mathrm{ky}$ BP snapshot is directly given by the AGCM simulations of Krinner et al. (2004). To construct the 105, 95 and $85 \mathrm{ky}$ BP snapshots, we assume that insolation changes are the primary causes of the climatic variations during the period considered. Siegert et al. (2001) shows that forcing the climate with insolation allows to build realistic Eurasian ice sheets through the full last glacial cycle. We take the impact of insolation changes into account by three means:

1. We use a glacial index proportional to summer (solstice) insolation at $65^{\circ} \mathrm{N}$. The climatic conditions vary from initial warm conditions (at $105 \mathrm{kyr} \mathrm{BP}$ ) to cold condi- tions. The lowest insolation occurs at $95 \mathrm{ka}$ (as presented in the Fig. 3).

2. Warm conditions prevail at 105 and $85 \mathrm{kyr}$ ago. Thus the snapshot derived from the control (GCM-P) climate is applied at these two dates.

3. The summer insolation reached its minimum at $95 \mathrm{kyr}$ BP while AGCM simulations were performed with orbital parameters for $90 \mathrm{kyr}$ ago (Krinner et al., 2004). Moreover AGCM $90 \mathrm{kyr}$ ago allows the maintenance of an existing ice sheet, but hardly glaciates an ice free Scandinavia (not shown). This is why we infer a colder climate for $95 \mathrm{kyr}$ BP.

To estimate the influence of summer insolation and correct the $95 \mathrm{kyr}$ BP snapshot, we use the sensitivity to insolation found, for Eurasia, in the PMIP experiments (Paleoclimate Model Intercomparison Project). In the framework of PMIP, AGCMs recontructed climatic conditions at several time periods, and in particular at $6 \mathrm{kyr}$ $\mathrm{BP}$ and for the present. The $6 \mathrm{kyr}$ conditions being similar to present except for insolation, we compared simulations performed by 12 selected models participating in PMIP. In average we found that summer temperatures in the northern Eurasian continent (between $60^{\circ}$ and $70^{\circ}$ North and $15^{\circ}$ and $60^{\circ}$ East) are $1.45^{\circ} \mathrm{C}$ higher at $6 \mathrm{kyr}$ compared to present. Given the summer insolation anomaly of $27 \mathrm{~W} \mathrm{~m}^{-2}$ at $6 \mathrm{ky} \mathrm{BP}$, we infer the influence of summer insolation on summer surface temperature to be $5.5 \times 10^{-2} \mathrm{k} \mathrm{W}^{-1} \mathrm{~m}^{2}$ in northern Eurasia. One could argue that the sensitivity to insolation is different between glacial and interglacial periods, in particular because of albedo changes. We tried to investigate this point with the LMD5 simulations used in Charbit et al. (2002). We compared sensitivity, to summer insolation both between 21 and $15 \mathrm{kyr}$, and between 6 and 0 kyr. We did not see signicant differences. Moreover, greenhouse gases concentrations, and surface elevation changes add important uncertainties.

Using this result, we reconstruct the coldest climate of $95 \mathrm{kyr}$ by decreasing AGCM $90 \mathrm{kyr}$ summer temperatures by $1.5^{\circ} \mathrm{C}$.

Oceans are also expected to influence the Eurasian ice sheet and the ice shelves. Heat exchanges melt the base of the floating ice and the sea level controls the flotation criterion and the grounding line position. In our simulations sea level evolution is given by Shackleton et al. (1990). The basal melting under Eurasian ice-shelves is our main unknown. We decid to impose a homogeneous basal melting which varies from $2.0 \mathrm{~m} \mathrm{a}^{-1}$ to $0.2 \mathrm{~m} \mathrm{a}^{-1}$ following the glacial index. In deep sea regions $(<-450 \mathrm{~m})$, very high basal melting $\left(8.0 \mathrm{~m} \mathrm{a}^{-1}\right)$ prevents ice shelf development and is justified by high heat exchanges with the deep ocean. 


\section{Surface elevation (89 ky BP)}
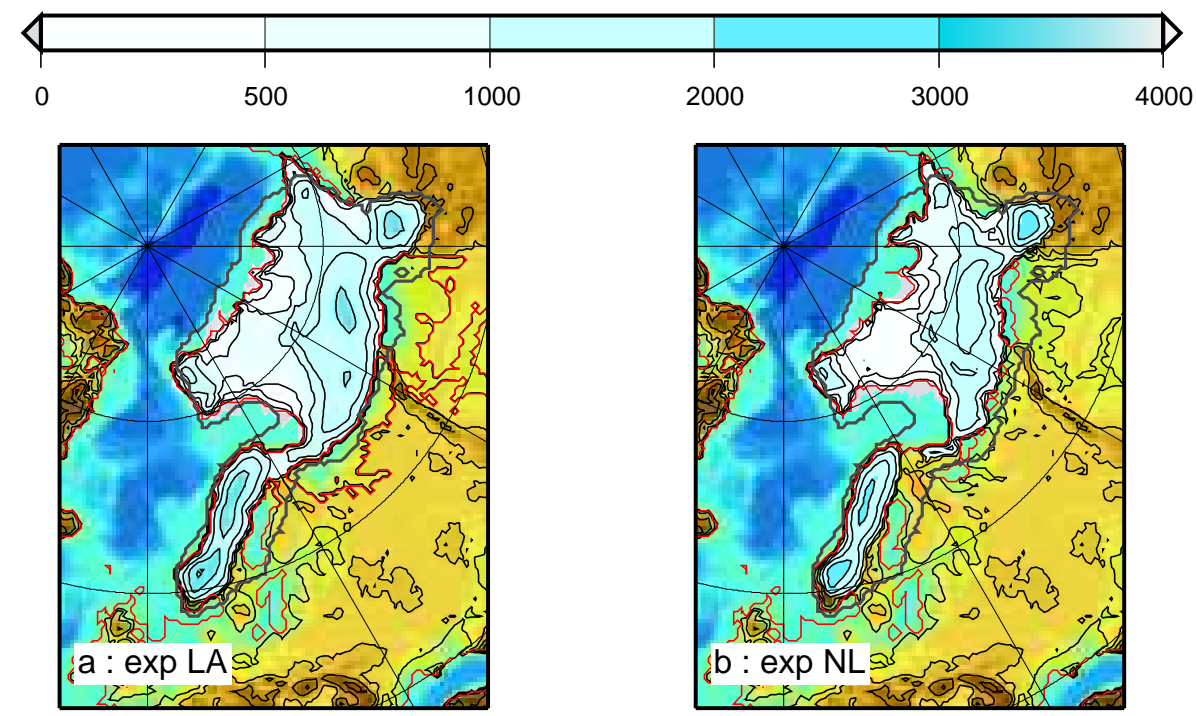

Fig. 4. Reconstructed ice sheet for the LA (a) and NL (b) experiments. Snapshot at $89 \mathrm{kyr}$ BP, close to the maximum ice volume.

\subsection{Experiments}

We perform 3 experiments. The first one uses the AGCM glacial climate without lakes (NL); the second uses AGCM climate with lakes (LA). In the LA experiment, the floatation is level is spacially variable. When ice dam existed (from 95 to $87 \mathrm{ky} \mathrm{BP}$, see below), we set the floatation level on the lake side to the observed lake altitude. According to Mangerud et al. (2004), the West Siberian Lake surface was around $60 \mathrm{~m}$ a.s.l., ice-dammed lakes in Pechora Low land (Lake Komi) and in the White Sea region were linked through a pass, and shorelines lay around $100 \mathrm{~m}$ above the sea level. Considering the sea level drop, the Baltic Sea was still linked with the North Sea.

The third experiment (MI) mixes the 2 previous experiments: we apply the no-lake (GCM-NL) climate from $105 \mathrm{kyr}$ until the moment when the extension of the simulated ice sheet leads to the formation of ice-dammed lakes. At this date, we switch to glacial climate with lakes (GCMLA). When lakes drained into Arctic ocean as a consequence of the simulated ice sheet decay, we switch back to the nolake climate until the end of the experiment.

\section{Results}

First we present the evolution of ice sheets for the 3 experiments and the differences induced by ice-dammed lakes. Then we describe the ice sheet dynamics trough the experiment MI.

\subsection{Influences of lakes}

\subsubsection{Timing}

The evolution of the ice sheets in the three experiments is drawn in the Fig. 3. The experiments present approximatively a similar timing with a maximum extent at the coldest period (95 kyr BP), and a maximum volume correlated with sea level drop - which reflects the real global (eustatic) ice volume.

In both experiments NL and LA, ice appears around $100 \mathrm{kyr}$ BP and expands until $94 \mathrm{kyr}$ BP. In the NL ice retreats as soon as summer insolation starts to increase, while in the LA, the presence of ice-dammed lakes maintains a large extent. This allows ice to thicken much longer, and consequently, in the LA the maximum ice sheet is 1.5 times bigger in volume. The presence of lakes also delays maximum volume and the deglaciation by $2 \mathrm{kyr}$.

The maximum volume is reached around $89 \mathrm{kyr} \mathrm{BP}$ in the LA experiment. Figure 4 depicts the two ice sheets (LA and $\mathrm{NL}$ ) at that date. The ice-dammed lakes maintain a large extent of the LA ice sheet until this date. In the LA experiment, ice expands further south and the junction between Scandinavia and Barents ice sheets is stronger. The ice is thicker (up to $200 \%$ in Barents Sea). According to our simulations, lakes appears early on the Siberian plains when the passage between Novaya Zemblya and Ural closes. Ice-dammed lakes in Pechora Low land (Lake Komi) and in White Sea appear when the Scandinavian and Barents ice sheets coalesce. Oppositely lakes disappear when the ice dams break. The timing of the lakes in simulations NL and LA is given in the Table 1. 
Table 1. Possible timing of ice-dammed lakes in experiment NL and LA. These date are obtained by visual interpretation of icedam formation between Ural and Novaya Zemlya for West Siberian Lakes, and between Barents ice sheet and Kola Penicula for the White Sea.

\begin{tabular}{lcc}
\hline Experiment & NL & LA \\
\hline Siberian Lakes & $96-97$ to $88.6 \mathrm{ky} \mathrm{BP}$ & $97-96$ to $87.5 \mathrm{ky} \mathrm{BP}$ \\
White Sea & 96 to $87 \mathrm{ky} \mathrm{BP}$ & 95.4 to $86.5 \mathrm{ky} \mathrm{BP}$ \\
\hline
\end{tabular}

To perform the mixed (MI) experiment, we start as for the NL because the lakes did not exist during the inception. Ice dammed lakes appear around 95 kyr BP (Table 1). We suppose that water from snow melt and rivers rapidely filled the lakes and thereby rapidely changes the climate. Thus we switch to (GCM-LA) climate at that time. Lakes influence the climate until ice-dams recede, which occurs at $87 \mathrm{kyr} \mathrm{BP}$ in the mixed experiment (as in LA). We expect the MI experiment to be the most realistic and enlight the dynamical effect induced by lake appearence and disappearence.

\subsubsection{MI experiment}

In the MI experiment (Fig. 3), lakes begin to influence the climate at $95 \mathrm{kr}$. In response to this switch, ice extends immediately and the volume rises at the same rate as in the LA experiment. During the deglaciation, when lakes are switched off, ice decay seems unaffected: the volume and extend are similar in the MI and the LA experiments. We conclude that lakes enhance the ice sheet inception and build-up. However, ice sheet decay is sensitive to the ice sheet volume. A huge ice sheet delays the deglaciation but the higher ablation (after lakes are swiched off) has no significant impact.

We tested the impact of floating of the ice over the lakes (lake surface is set at $60 \mathrm{~m}$ a.s.l. on Siberian plain and $100 \mathrm{~m}$ a.s.l. for Lake Komi and the White Sea). This does not influence the ice sheet because it is too thick to float. Only high basal melting $\left(>2 \mathrm{~m} \mathrm{a}^{-1}\right)$ at the grounding line has a significant effect (northward retreat of the ice). Considering that observed calving rates in freshwater are usually low (Vieli et al., 2001), and that in the AGCM simulations, the lakes where ice covered most of the year, we did not investigate the role of lacustrine calving any further. On the other hand, though the ice in the model grid cell is too thick to float, in reality the thickness decreases sharply as one approaches the margin. Furthermore, the lack of well-constrained calving model and the use of a simplified isostatic model adds further uncertainties.

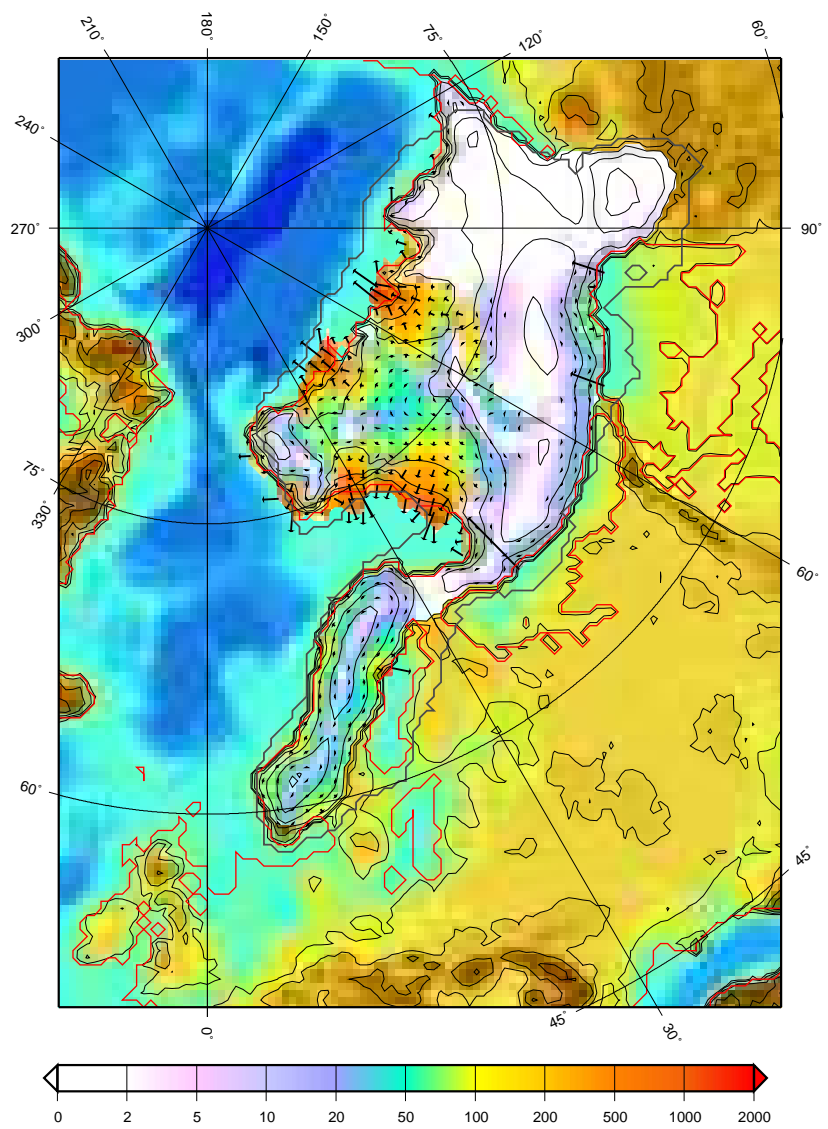

Fig. 5. Horizontal ice velocity of experiment MI $89 \mathrm{kyr}$ BP, close to the maximum ice volume. Kara sea is covered by a high slow moving ice dome. Barents Sea presents large ice streams in the topographic throughts.

3.2 Description of the dynamics of ice in the mixed (MI) experiment

Inception occurs in the Arctic archipelago, on highlands (Scotland, Scandinavia, Putorana) and over the Siberian plain (Fig. 6a). By 98 kyr BP fringing ice shelves around Novaya Zemblya and Siberia join on Kara Sea (Fig. 6b). Soon after, ice grounds in this area that will become the center of mass of the future ice sheet (Fig. 6c). Between 97000 and 96500 years BP (Figs. 6c-e), while basal melting below the ice shelves decreases and surface mass balance increases, unconfined ice shelves spread over from the coast and islands. This floating ice encounters islands and grounds on shallows.

The resulting longitudinal stresses backforce slows down the upstream ice and enhance ice shelf thickening. When ice covers the Barents Sea (i.e. ice shelves from Spitsberg, Franz Joseph Land and Novaya Zemblya coalesce) the buttressing effect confines the whole area, and ice grounds between 96 and $95 \mathrm{kyr}$ BP (Figs. 6e-f). Maximum extent is reached after $95 \mathrm{kyr}$ BP and remains stable during several thousands of 

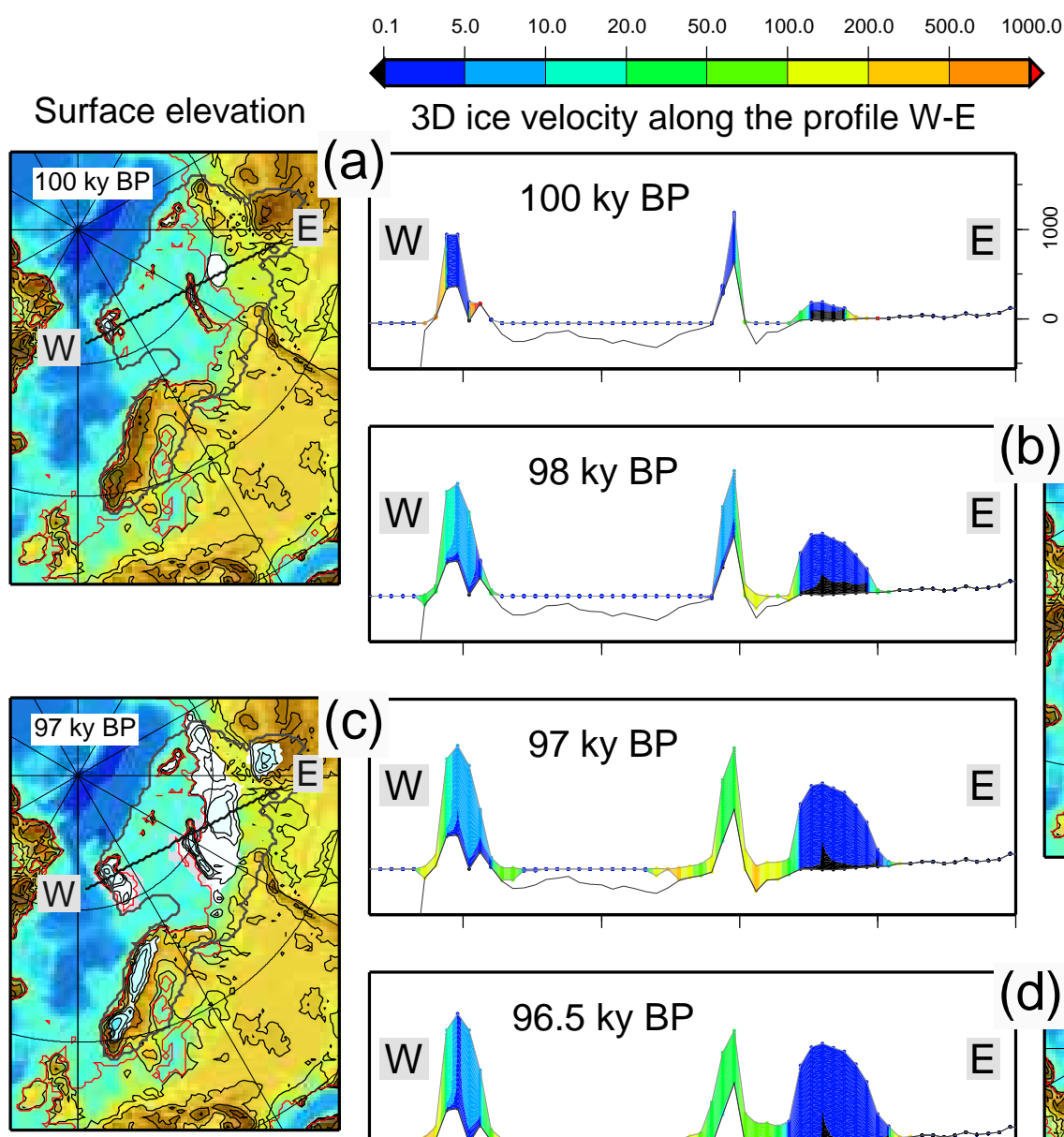

(c)

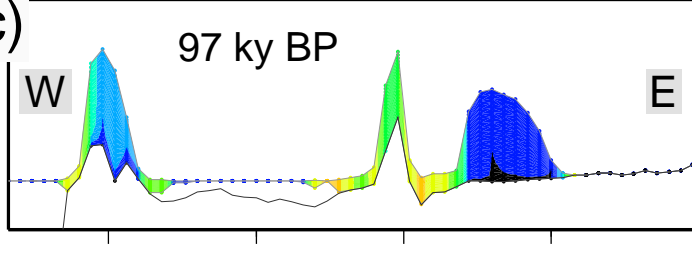

(b) $98 \mathrm{ky} \mathrm{BP}$
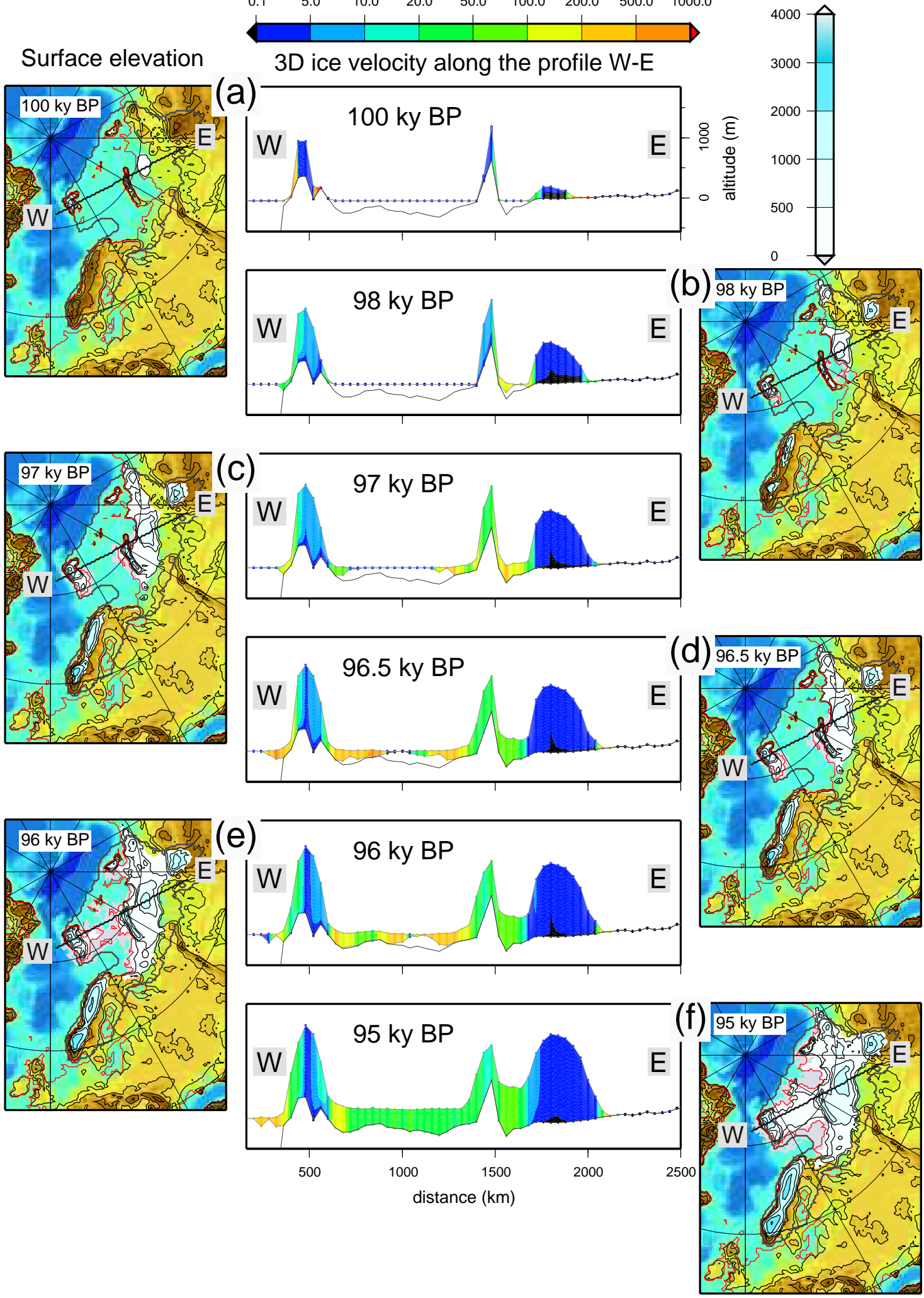

Fig. 6. 6 snapshots during the MI inception. At each time, ice sheet surface elevation and ice velocity along the profile W-E are presented (central boxes). Grounding line is pictured in red, ice shelves surface is in grey (elevation $<0 \mathrm{~m}$ ). These snapshots focus on the role of the floating part (ice shelves surface elevation in grey). 

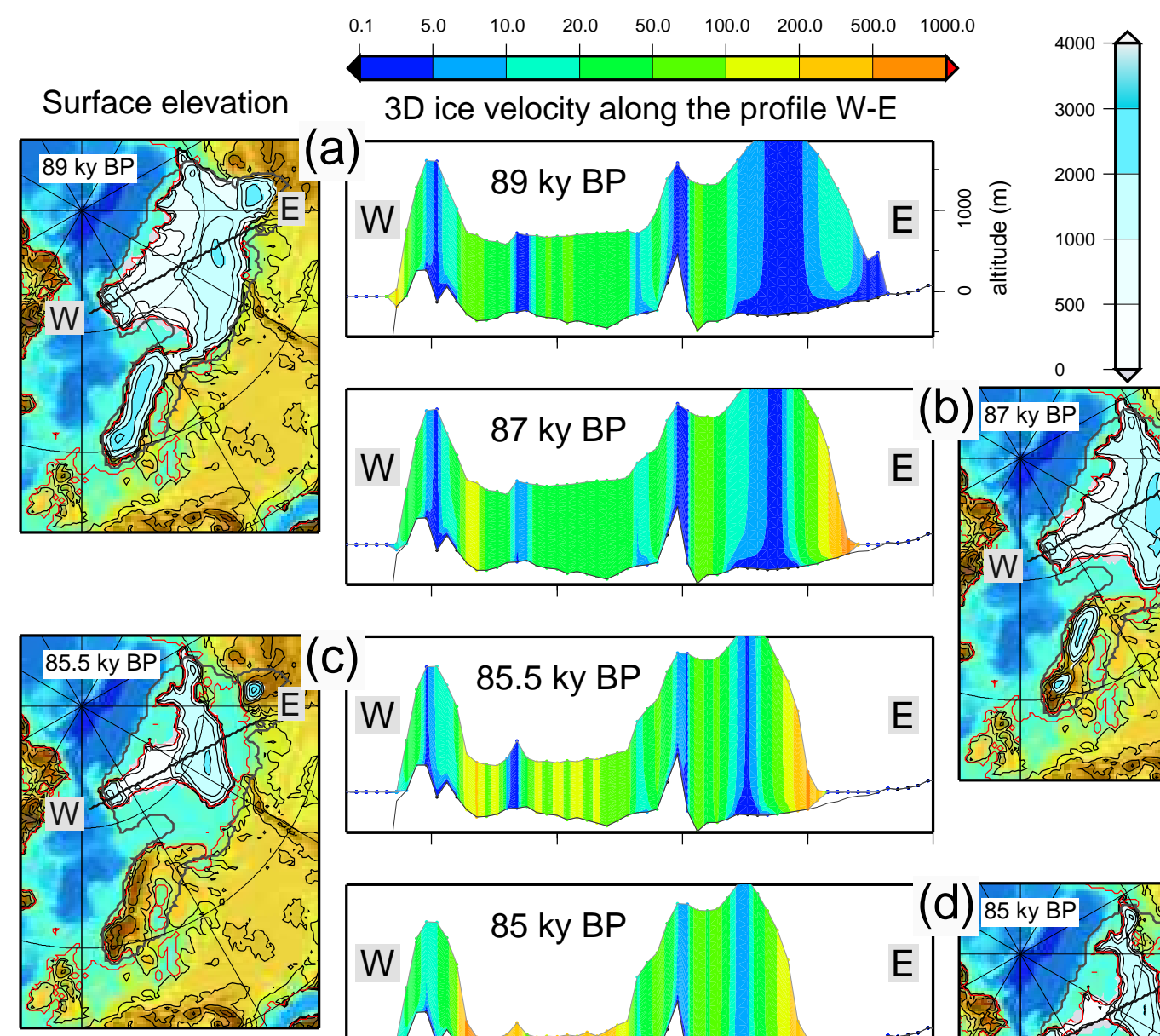

(b) $87 \mathrm{ky} \mathrm{BP}$
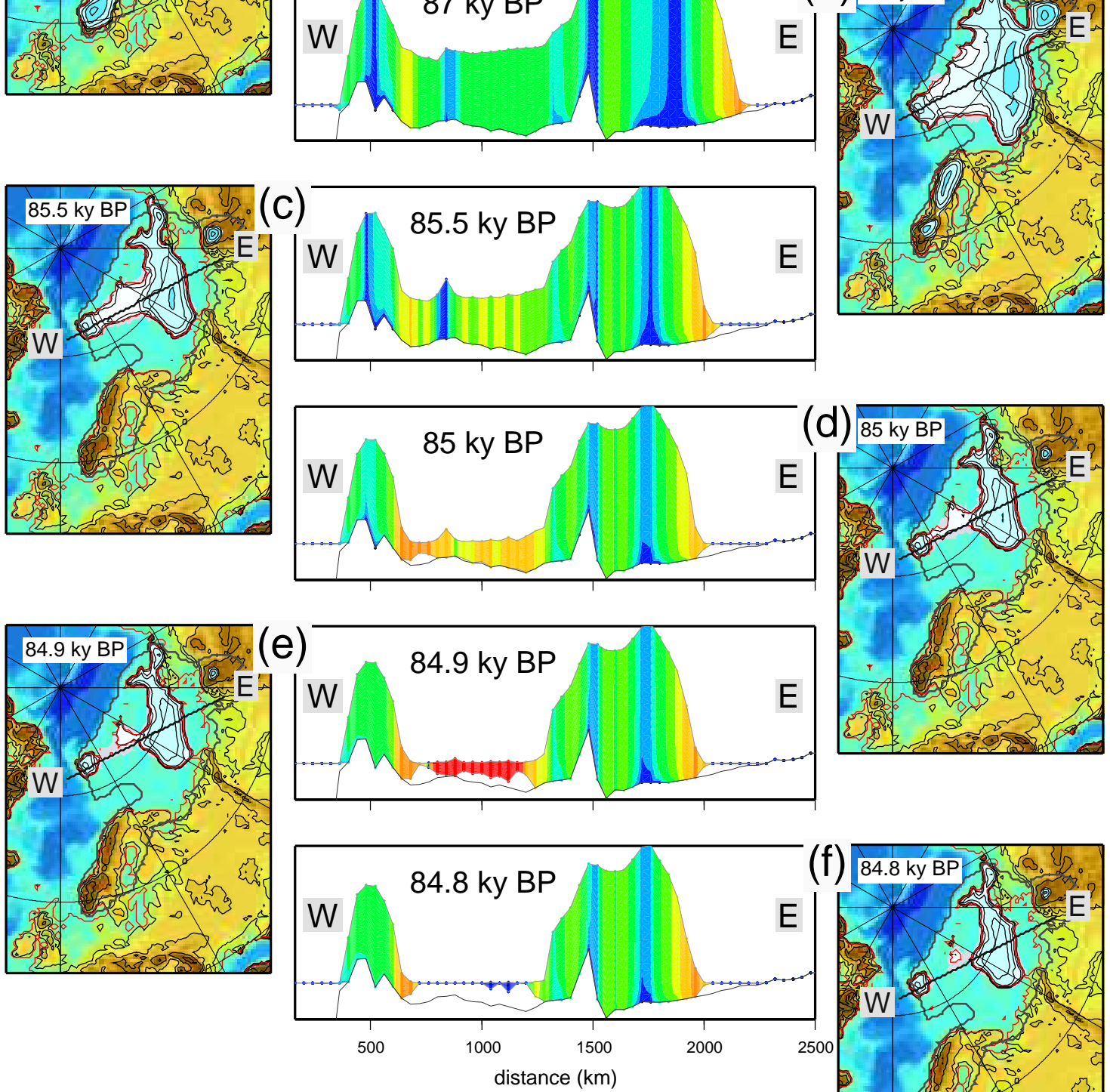

Fig. 7. Snapshots during the deglaciation in the MI experiments. At each time ice sheet surface elevation and ice velocity along the profile are presented. The Barents ice sheet break off occurs within a few centuries. 
years. The ice sheet reaches its maximum volume around 89 kyr ago (Fig. 4a). The velocity field presented in Fig. 5 shows slow ice in Siberia, where the bed stays frozen. Enhanced by high accumulation, an elevated ice ridge appears on the south of the ice sheet. In areas where ice shelves grounded, velocities stay high and ice streams appear in the topographic troughs. A particularly long ice stream develops on Kara sea, along Novaya Zemlya down to St. Anna trough. This stream causes a saddle that separates two domes on the ice sheet ridge. The high discharge rates of the Barents Sea leads to a very flat ice sheet. Its thickness never exceeds $2000 \mathrm{~m}$.

During the deglaciation, presented in Fig. 7, the Barents and Scandinavian ice sheets split at $88 \mathrm{kyr}$ BP. The ice recedes to the North and the East. More stable features are the Kara ice sheet and another ice sheet North of Barents Sea leaning on Spitsberg, Franz Joseph Land and Novaya Zemblya (Fig. 7b). This last feature disintegrates within two hundred years between 85 and 84.8 kyr BP (Figs. 7c-f). As ablation increases, ice thins to its flotation limit. When ice starts to float, high basal melting appears and the ice shelf therefore thins more rapidly. Furthermore, longitudinal stresses decrease and the upstream grounded ice accelerates. The snapshot at $85 \mathrm{ky}$ BP (Fig. 7d) captures the moment when bulk of the ice sheet start to float, the ice is unconfined and velocities rises up to several thousands of meter per year. After this catastrophic break off, ice is constrained within Arctic islands where it slowly recedes to ice free conditions (Fig. 7f).

\section{Discussion}

\subsection{Temporal evolution of the climate forcing}

The temporal evolution of the climate forcing is a critical input for the ice sheet model. Unfortunately, AGCM climate forcing was only available for $90 \mathrm{kyr} \mathrm{BP}$ and for the present. This led us to reconstruct intermediate climate states as a function of the available baseline climates and of orbitally driven summer insolation anomalies. To a certain degree, our forcing method thus allows to test the hypothesis that the Early Weichselian glacial event is driven by orbital summer insolation variations. As the ice sheet model does indeed reproduce the ice sheet growth and decay in a fairly plausible manner, this seems to confirm the assumption of a major role of the orbital forcing.

In this work, the forcing method neglects the fact that the season lengths also depend on the orbital parameters (Joussaume and Braconnot, 1997); Precessional orbital variations (the $20 \mathrm{kyr}$ band) are such that a summer insolation maximum is coincident with a minimum of the length of that season. Here we only assumed changes of summer (JJA) temperature according the summer solstice insolation $\left(60^{\circ} \mathrm{N}\right)$. But albation is highly non linear with temperature; and even with our sinusoidal variations of temperature through the year, $50 \%$ of PDD (ie ablation) is concentrated during the warmest month. Neverthess, it would be obviously preferable to take into account variations of season lengths in calculating the monthly and thus annual surface mass balance.

\subsection{Ice sheet extent}

Experiments MI and LA yield a huge ice sheet, in agreement with the QUEEN reconstruction (Svendsen et al., 2004). The difference between simulations LA and NL is mainly due to reduced ablation on the southern flanks of the ice sheets. Precipitation is slightly higher in NL, but this effect is negligible compared to the ablation increase. In our simulations, we have chosen the melting ceofficients such that the GCMsimulated melt rates are reproduced in the ice sheet model simulations. These coefficients are three time higher than those usually taken in comparable modeling exercises (Reeh, 1991) and limit the southward extension of the ice sheet. In particular, the modelled ice sheet does not reach the southern limit of the QUEEN reconstruction. However, the GCM simulations with and without lakes differ particularly strongly over and in the immediate vicinity of the ice-dammed lakes (Fig. 3). This means that the ice sheet regions where the simulated climates in the two GCM simulations differ most strongly are actually not ice-covered in the GRISLI simulations. Therefore the difference between the two climatic states from the GCM does not unfold its full impact in the ice sheet model simulations.

Our results thus confirm that ice-dammed lakes do have an influence on ice sheets that should not be neglected. However, the amplitude of the impact of the lakes is very sensitive to the baseline mass balance.

\subsection{Simulated and observed isostatic responses}

The degree of realism of our model results can be assessed by analysing the modelled isostatic response. Mangerud et al. (2004) observed that the shorelines of the lake Komi range from $90 \mathrm{~m}$ above the present sea level (a.s.l.) in the south to $110 \mathrm{~m}$ a.s.1. in the north, and are at about $60 \mathrm{~m}$ a.s.1. in West Siberia. In our experiments, the ice sheets thicken until $89 \mathrm{kyr} \mathrm{BP}$, and the isostatic depletion reaches $200 \mathrm{~m}$ on the southern limit in experiment LA. Regionally, close to the icedammed lakes, the isostatic depletion is such that the continental surface drops below sea level (see Fig. 4). This overestimate of the isostatic depletion suggests that the simulated Siberian ice sheet is too massive. The probable reason is that the LMDZ4 AGCM overestimates the precipitation is this region (as in the control AGCM simulation labelled P).

\subsection{Lake ages}

Mangerud et al. (2004) dated Lake Komi on the Pechora Low Land between 90 and $80 \mathrm{ky}$ BP, with ages subject to large uncertainties. Our reconstruction suggests that the lakes existed from 95 to $87 \mathrm{ky} \mathrm{BP}$ (see Table 1). Simulations LA and NL 
give similar durations of 8000 to 9000 years. The simulated ice dam linking the Barents Sea ice sheet and the Scandinavian ice sheet is small, and possibly existed only during a few thousand years. Therefore, the postulated White Sea Lake might have broken this dam and might have drained across it through subglacial drainage, similar to what was suggested for Lake Agassiz (Clarke et al., 2004). Moreover, the "QUEEN-team" working in the white sea basin observed only rare material deposit that confirm the existence of a lake at that date (Houmark-Nielse et al., 2001). The lack of deposit may be due to a shorter lake existence, as suggested by our simulations.

\subsection{Deglaciation and fresh water fluxes to the oceans}

During the deglaciation, hight calving rates and freshwater release due to the sudden drainage of the ice dammed lakes drainage are supposed, in accordance with marine sediment deposits (Spielhagen et al., 1997). Our simulations suggest a delay of 1000 years between drainage of Lake Komi and that of the West Siberian lake. Such freshwater discharges can in principle influence oceanic circulation, but the location of the freshwater input (either the Barents Sea, that is the North Atlantic, or the Arctic Ocean) is critical as it determines the climatic impact of the event. Fig. $7 \mathrm{~b}$ clearly suggests that the White Sea Lake and Lake Komi drained into the Barents Sea. The larger West Siberian Lake might have drained either into the Barents Sea or the Arctic Ocean. In the MI experiment, two ice dams persist during the ice sheet retreat in Siberia (Fig. 7c). The first dam joins Novaya Zemlya to the Taimir Penisula, the second links Novaya Zemlya to the Urals. During ice retreat, two possible outlets appears between the Putorana and Taimir and between Ural and Kara sea (Figs. 7b, c). Analyse of the water treshold (not shown) might suggest that the lake drained into the Barents Sea through this latter passage. Finally, it is worth noting that in our simulations, final volume of the lakes before the outburst might have been much larger than what was inferred by Mangerud et al. (2004) because when the ice sheet retreats, the lakes expand.

\subsection{Ice sheet inception in Siberia}

Our reconstructions situate the ice sheet inception on the Siberian emerged land, rather than on Arctic archipelagos. The low temperatures and high precipitations (in experiment LA) lead to a high dome (thicker than the observed isostatic depletion suggests, as discussed above). The reason is that before $97 \mathrm{ky}$ (in exp MI, see Fig. 6), grounded ice can extend freely on emerged land of the Kara Sea, while ice is restricted to the islands by high basal melting under fringing ice shelves.

The inception of a marine ice sheet is limited by oceanic conditions. Some authors (e.g., Kenneally and Hughes, 2002) argue that calving is too important to allow ice caps to advance across seas or interisland channels and coalesce. They proposed that marine inception is due to sea ice thickening and formation of fast ice in which icebergs are catched (Marine Transgression hypotheses). Our simulations show that with a true ice shelf model this hypothesis is not necessary. Furthermore, sensitivity experiments (not shown) have demonstrated that the existence of an ice shelf is indeed necessary to explain the glaciation of Kara and Barents Seas.

Since GRISLI ISM simulations of the West Antarctic ice shelves reproduce well the observed ice shelves, we are confident in the present reconstruction.

\section{Conclusion}

We reconstructed the Eurasian ice sheet through the Early Weichselian (90 kyr ago). We performed three simulations using AGCM climate with and without the influence of icedammed lakes, applying the reconstructed climate to the GRISLI ice sheet model. The simulation NL did not include lakes, while LA did. From these two simulations we inferred that ice-dammed lakes existed from 95 to $87 \mathrm{kyr}$ BP on the south of the ice sheet. The climate forcing in the third ISM simulation (MI) was initially an adapted AGCM climate without lakes. At the point where the reconstructed ice sheet was large enough to dam northward flowing rivers, the forcing was switched to an AGCM climate taking into account the climatic impact of the proglacial lakes. After the simulated disappearance of the ice dams, we switched back to the initial climate forcing without lakes. This experiment constructed and disintegrated ice sheets in accordance with geomorphological evidences. the simulated ice streams are very efficient in draining the ice sheet, especially in the Barents and Kara sea. Lakes have a great influence during inception. Maximum ice volume is $50 \%$ higher in LA compared to simulation NL, and deglaciation is delayed by $2 \mathrm{kyr}$. Moreover the impact of lakes is probably underestimated because our ice sheet does not reach the shoreline of the lakes in the AGCM simulations where the climatic conditions show the largest difference. We also studied the impact of ice shelves on the Barents ice sheet. Inception occurs by thickening of a large ice shelf that is slowed down by islands and ice rises. This seems reasonable. Deglaciation occurs in a few centuries when the surface mass balance decreases (as a consequence of orbitally-induced summer surface temperature variations) and the ice thickness consequently decreases below the floating level. The ice then begins to float and disintegrates immediately. The modelled deglaciation is characterized by high calving rates and the freshwater release due to the drainage of the ice dammed lakes in accordance with observations from marine sediments.

This study confirms that and illustrates how ice-dammed lakes influence adjacent ice sheets. It would be interesting to investigate in more detail the realism of our reconstruction with isostatic considerations, and to investigate the volume 
and drainage pattern of the ice sheet at higher model resolution. Further works should also improve the climate forcing.

Acknowledgements. The simulations were carried out of the MIRAGE computer platform in Grenoble. We thank N. Shapiro for providing us with his geothermal heat flux map for the northern hemisphere. The graphics were produced using the GMT software (Wessel and Smith, 1991). This work was supported by the MOTIF program.

Edited by: P. Braconnot

\section{References}

Charbit, S., Ritz, C., and Ramstein, G.: Simulations of northern hemisphere ice-sheet retreat: sensitivity to physical mechanisms involved during the Last Deglaciation, Quat. Sci. Rev., 21, 243265, 2002.

Clarke, G. K., Leverington, D., Teller, J., and Dyke, A.: Paleohydraulics of the last outburst flood from glacial Lake Agassiz and the 8200 BP cold event, Quat. Sci. Rev., 23, 399-407, 2004.

Fortuin, J. P. F. and Oerlemans, J.: Parametrisation of the annual surface temperature and mass balance of Antarctica, Ann. Glaciol., 14, 78-84, 1990.

Houmark-Nielse, M., Demidov, I., Funder, S., Grfjeld, K., Kjær, K. H., Larsen, E., Lavrova, N., Lyså, A., and Nielsen, J. K.: Early and Middle Waldaian glaciations, ice dammed lakes and periglacial interstadials in the northwest Russia: new evidence from Pyoza River area, Glob. Planet. Change, 31, 215-237, 2001.

Hutter, K.: Theoretical Glaciology, D. Reidel, Norwell, Mass., 1983.

Jackson, C. S. and Broccoli, A. J.: Orbital forcing of Arctic climate: mechanisms of climate response and implication for continental glaciation, Clim. Dyn., 21, 539-557, 2003.

Joussaume, S. and Braconnot, P.: Sensitivity of paleoclimate simulation results to season definitions, J. Geophys. Res., 102, 19431956, 1997.

Kenneally, J. and Hughes, T.: The calving constraints on inception of Quaternary ice sheets, Quat. Int., 95-96, 31,943-31,964, 2002.

Krinner, G. and Genthon, C.: Altitude dependance of the ice sheet surface climate, Geophys. Res. Lett., 26, 2227-2230, 1999.

Krinner, G., Mangerud, J., Jakobsson, M., Crucifix, M., Ritz, C., and Svendsen, J.: Enhanced ice sheet growth in Eurasia owing to adjacent ice-dammed lakes, Nature, 427, 429-432, 2004.

Krinner, G., Magand, O., Simmonds, I., Genthon, C., and Dufresne, J.-L.: Simulated Antarctic precipitation and surface mass balance at the end of the twentieth and twenty-first centuries, Clim. Dynam., 28(2-3), 215-230, doi:10.1007/s00382-006-0177-x, 2006.

Le Meur, E. and Huybrechts, P.: A comparison of the different ways of dealing with isostasy: examples from modelling the Antartic ice sheet during the last glacial cycle, Ann. Glaciol., 23, 309317, 1996.

MacAyeal, D. R.: Large Scale ice flow over a vicous basal Sediment: Theory and Application to Ice Stream B, Antarctica, J. Geophys. Res., 94, 4071-4087, 1989.
Mangerud, M., Jakobsson, M., Alexanderson, H., Astakhov, V., Clarke, G. K. C., Henriksen, M., Hjort, C., Krinner, G., Lunkka, J.-P., Möller, P., Muray, A., Nikolskaya, O., Saarnisto, M., and Svendsen, J. I.: Ice-dammed lakes and rerouting of the drainage of northern Eurasia during the Last Glaciation, Quat. Sci. Rev., 23, 1331-1332, 2004.

Marshall, S., Sharp, M., Burgess, D., and Anslow, F.: Near-surface temperature lapse rate variability on the Prince of Wales Icefield, Ellesmere Island, Nunavut: Implication for regional-scale temperature downscaling, Int. J. Clim., 27(3), 385-398, 2007.

Mercer, J. H.: West Antarctic Ice Sheet and CO2 greenhouse effect: a threat of disaster, Nature, 271, 321-325, 1978.

Morland, L.: Thermo-mechanical balances of ice sheet flow, Geophys. Astrophys. Fluid Dyn., 29, 237-266, 1984.

Oppenheimer, M.: Global warming and the stability of the West Antarctic Ice Sheet, Nature, 393, 325-332, 1998.

Paillard, D., Labeyrie, L., and Yiou, P.: Macintosh Program Performs Time-Series Analysis, in: EOS Transactions, vol. 77, p. 379, AGU, 1996.

Reeh, N.: Parametrization of melt rate and surface temperature on the Greenland ice-sheet, Polarforschung, 59, 113-128, 1991.

Ritz, C., Rommeleare, V., and Dumas, C.: Modeling the evolution of Antarctic ice sheet over the last 420,000 years: Implications for altitude changes in the Vostok region, J. Geophys. Res., 106, 31 943-31 964, 2001.

Rommelaere, V. and Ritz, C.: A thermomechanical model of iceshelf flow, Ann. Glaciol., 23, 13-20, 1996.

Ruddiman, W. F. and McIntyre, A.: Oceanic Mechanisms for Amplification of the 23,000-Year Ice-Volume Cycle, Science, 212, 617-627, 1981.

Shackleton, N., Berger, A., and Peltier, W.: An alternative astronomical calibration of the lower Pleistocene timescale based on ODP Site 677, Trans. R. Soc. Edinb. Earth Sci., 81, 251-261, 1990.

Shapiro, N. M. and Ritzwoller, M. H.: Inferring surface heat flux distributions guided by a global seismic model: particular application to Antarctica, Earth Planet. Sci. Lett., 223, 213-224, 2004.

Siegert, M., Dowdeswell, J. A., Hald, M., and J.-I., S.: Modelling the Eurasian Ice Sheet through a full (Weichselian) glacial cycle, Glob. Planet. Change, 31, 367-385, 2001.

Spielhagen, R., Bonani, G., Eisenhauer, A., Frank, M., Frederichs, T., Kassens, H., Kubik, P., Mangini, A., Norgaard-Pedersen, N., Nowaczyk, N., Schaper, S., Stein, R., Thiede, J., Tiedemann, R., and Wahsner, M.: Arctic Ocean evidence for Late Quaternary initiation of northern Eurasian ice sheets, Geology, 25, 783-786, 1997.

Svendsen, J. I., Alexanderson, H., Astakhov, V., Demidov, I., Dowdeswell, J., Funder, S., Gataullin, V. ., Henriksen, M., Hjort, C., Houmark-Nielsen, M., Hubberten, H., Ingiólfsson, I., Jakobsson, M., Kjærr, K., Larsen, E., Lokrantz, H., Lunkka, J.-P., Lyså, A., Mangerud, J., Matiouchkov, A., Murray, A., M öller, P., Niessen, F., Nikolskaya, O., Polyak, L., Saarnisto, M., Siegert, C., M.J., S., R., S., and Stein, R.: Late Quaternary ice sheet history of Northern Eurasia, Quat. Sci. Rev., 23, 1229-1271, 2004.

Vieli, A., Funk, M., and Blatter, H.: Flow dynamics of tidewater glaciers: a numerical modelling approach, J. Glaciol., 47, 595606, 2001. 
Wessel, P. and Smith, W. H. F.: Free software helps map and display data, EOS Trans. AGU, 72, 441, 1991.

Zweck, C. and Huybrechts, P.: Modeling of the northern hemisphere ice sheets during the last glacial cycle and glaciological sensitivity, J. Geophys. Res., 110, L18 402, doi:10.1029/2004JD005 489, 2005. 